\title{
Fiscal Sustainability of the German Laender Time Series Evidence
}

\author{
Heiko T. Burret \\ Lars P. Feld \\ Ekkehard A. Köhler
}

CESIFO WORKING PAPER NO. 4928

CATEgory 1: Public FinANCE

August 2014

An electronic version of the paper may be downloaded

- from the SSRN website:

- from the RePEc website:

- from the CESifo website:

WWW.SSRN.com

www.RePEc.org

www.CESifo-group.org/wp

\section{CESifo}




\title{
Fiscal Sustainability of the German Laender Time Series Evidence
}

\begin{abstract}
In this paper we analyze the sustainability of public finances in the states (Laender) of the Federal Republic of Germany using an unprecedentedly comprehensive fiscal dataset for the time period from 1950 to 2011 for West German Laender and 1991 to 2011 for East German Laender, respectively. In order to assess the fiscal sustainability of the (Laender) we, first, examine the stationarity characteristics of public debt, revenues and expenditures. Second, we explore the long-run relation between expenditures and revenues in a cointegration analysis within each Land. The results provide evidence against strict fiscal sustainability in most of the 16 German Laender. A notable exception to this finding is Bavaria.
\end{abstract}

JEL-Code: H620, H770, H720.

Keywords: fiscal sustainability, federalism, unit root, cointegration, public debt.

Heiko T. Burret

Walter Eucken Institute

Goethestr. 10

Germany - 79100 Freiburg

burret@eucken.de
Lars $P$. Feld

Walter Eucken Institute and Albert-Ludwigs-University Freiburg

Goethestr. 10

Germany - 79100 Freiburg

feld@eucken.de

Ekkehard A. Köhler

Walter Eucken Institute

Goethestr. 10

Germany-79100 Freiburg

koehler@eucken.de

We would like to thank Konstantin Klemmer, Daniel Nientiedt, Adrian Ochs and Leonardo Palhuca for valuable research assistance and Peter Hatzmann from the Federal Statistical Office for providing us the best data available. 


\section{Introduction}

Despite the relevance of sub-federal finances for fiscal sustainability in Germany, most studies primarily focus on public finances of general government (Afonso 2005, Bravo and Silvestre 2002, Greiner et al. 2006, Greiner and Kauermann 2007, 2008, Grilli 1988, Payne 1997, Polito and Wickens 2011). However, in federal states, the sub-federal level can be crucial for fiscal sustainability. Regional state and local government finances cover a notable share of general public finances. In addition, the fiscal framework might induce moral hazard leading to unsustainable fiscal policies on the regional and local levels. In particular, consolidation efforts may be curbed when lower-tier governments form bail-out expectations.

For these reasons, this paper focuses on the sub-federal level and econometrically tests whether public finances of the German federal states (Laender) are sustainable. Germany is chosen as a case study for three important reasons. First, the sub-federal level in Germany owes a significant amount of total debt (approximately 40\%). Thus, general fiscal sustainability could seriously be endangered. Second, two Laender obtained a constitutionally granted bailout in 1992 creating the above-mentioned incentives for unsound fiscal policies at the level of the Laender. Third, the Laender are required to balance their budgets until 2020 to comply with the German debt brake. A sustainability analysis of Laender finances additionally hints at their consolidation requirements in the near future.

Previous time series analyses of fiscal sustainability of the German Laender (e.g., Kitterer 2007; Claeys et al. 2008; Herzog 2010; Fincke and Greiner 2011) show several notable shortcomings: First, the validity of most test results remains fairly limited since the time period covered by the univariate analyses is relatively short (e.g., Fincke and Greiner 2011; Claeys et al. 2008). Second, most univariate analyses do not control for structural breaks, even though trends and other time series characteristics are important to consider in fiscal data (e.g., Fincke and Greiner 2011; Claeys et al. 2008). Third, the years of the Great Recession and the time period of the "German economic miracle" is covered by none of the four papers mentioned above. Fourth, in all four studies only a subset of the German Laender is considered. Thus, our paper contributes to the current literature in two ways: On the one hand, we provide an in-depth analysis of the sustainability of all 16 German Laender finances by considering a longer time period. On the other hand, we apply a broader arsenal of econometric tests based on the theoretical background from the literature. 
The remainder of the paper is organized as follows: Section 2 briefly describes the dataset and the test strategy. In Section 3 the results are presented in consecutive steps. Conclusions are offered in Section 4.

\section{Data and Methodology}

\subsection{Data}

The empirical analysis is based on annual data covering public expenditures, revenues and public debt of the 16 German Laender. The sample comprises the years 1950-2011 for the West German Laender and the years 1992-2011 for the East German Laender (Brandenburg, Mecklenburg-Western Pomerania, Saxony, Saxony-Anhalt, Thuringia and Berlin). ${ }^{1}$ The variables are measured as ratios of imputed $\mathrm{GDP}^{2}$ of the Laender in order to get a more natural definition of fiscal sustainability (Kirchgässner and Prohl 2008) and to achieve similarly scaled series that offer more credible information (Bohn 2008). Figure 1 shows the development of public finances in different groups of the Laender. Interestingly, the three city states (Berlin, Bremen, Hamburg) reveal substantially higher expenditures, revenues and debt. Contrarily, public finances of the other West German Laender seem to be in a better state. While Laender regularly achieved a fiscal surplus during the 1950s and 1960s, fiscal deficits have been all too frequent in subsequent years.

Figure 1 Development of Public Finances by Laender Groups

Expenditure

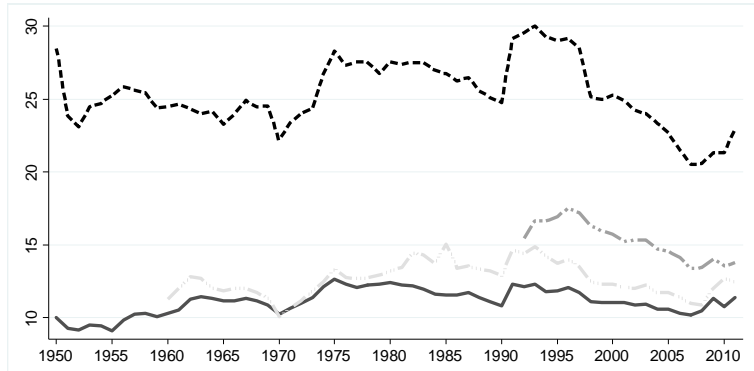

Revenue

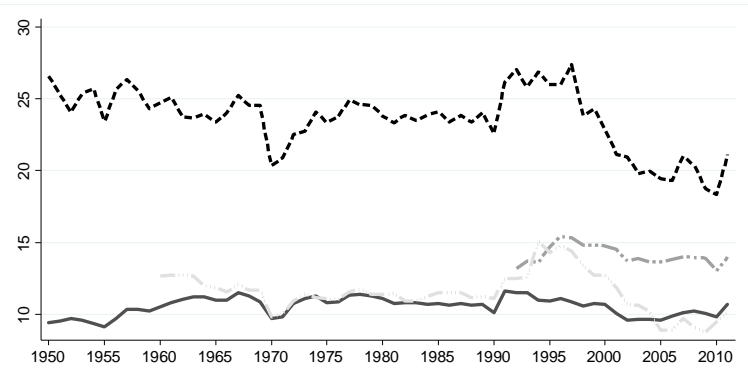

\footnotetext{
${ }^{1}$ Data on public debt could not be obtained before 1955. The time series for Saarland do not start before 1960. The sample does not include local fiscal data. In 1960, data on expenditures and revenues is only available between April and December (short fiscal year). Thus, we derived the missing values through interpolation and in the case of Saarland through extrapolation. Further information on the data and descriptive statistics are provided in Table A.7 and A.8.

2 Since data on GDP of the Laender is not reliable we use imputed GDP instead. This is derived by multiplying national GDP per capita in year $t$ with the population of the respective Land in year $t$.
} 
Debt

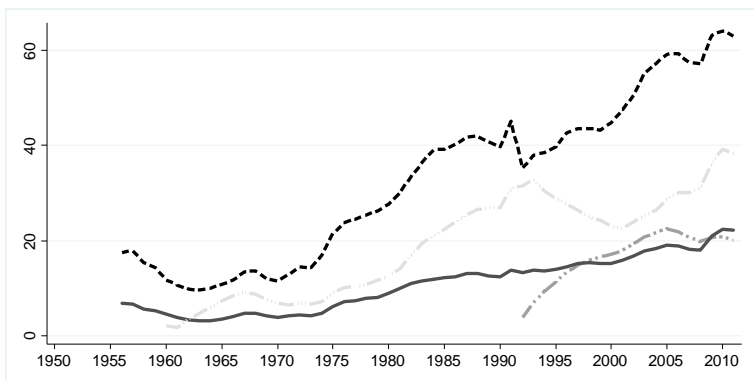

Gross deficit

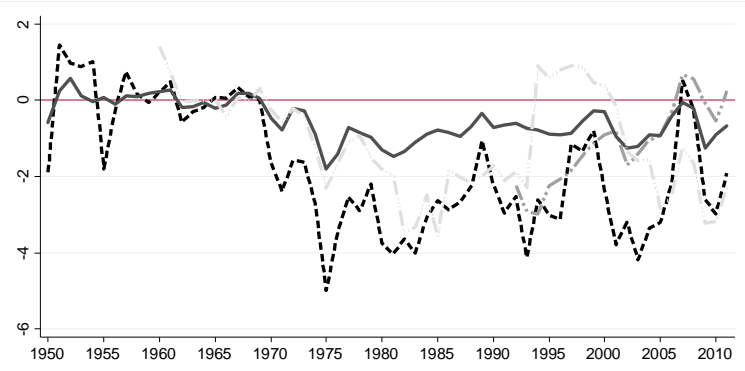

City Laender (HE, HB, HH)

West German Laender (RP, BW, BY, HE, NI, NW, SH)

-."- East German Laender (BB, MW, SN, ST, TH) Saarland (SL)

Note: City states include Berlin (BE), Bremen (HB) and Hamburg (HH). East German Laender include Brandenburg (BW), MecklenburgWestern Pomerania (MW), Sachsen (SN), Sachsen-Anhalt (ST) and Thuringia (TH). West German Laender include Rhineland-Palatinate (RP), Baden-Wuerttemberg (BW), Hesse (HE), Lower Saxony (NI), North-Rhine Westphalia (NW) and Schleswig-Holstein (SH), while the Saarland $(\mathrm{SL})$ is depicted separately since its time series starts not before 1960.

\subsection{Methodology}

We investigate fiscal sustainability separately for each Land by testing a sustainability condition derived from the present value budget constraint. ${ }^{3}$ The sustainability condition requires the discounted present value of public debt to converge to zero in infinity and initial debt to equal the expected present value of future primary surpluses. This condition is assumed to be met if:

- Public debt follows a stationary process I(0), i.e. its variance and mean are stable across time, or

- in case of a non-stationary public debt series, i.e. I(1), if total revenues and expenditures are cointegrated with a vector of $[1,-1]$, whereas the individual time series may be non-stationary (Bohn 2008, Burret et al. 2013, Larin and Süßmuth 2014).

Based on these considerations, our empirical test strategy proceeds in three consecutive steps (Figure 2):

\footnotetext{
${ }^{3}$ In a companion paper we test Laender panels (Burret et al. 2014).
} 
Figure 2 Three-step Time Series Test Procedure for Expenditure and Revenue of each Land

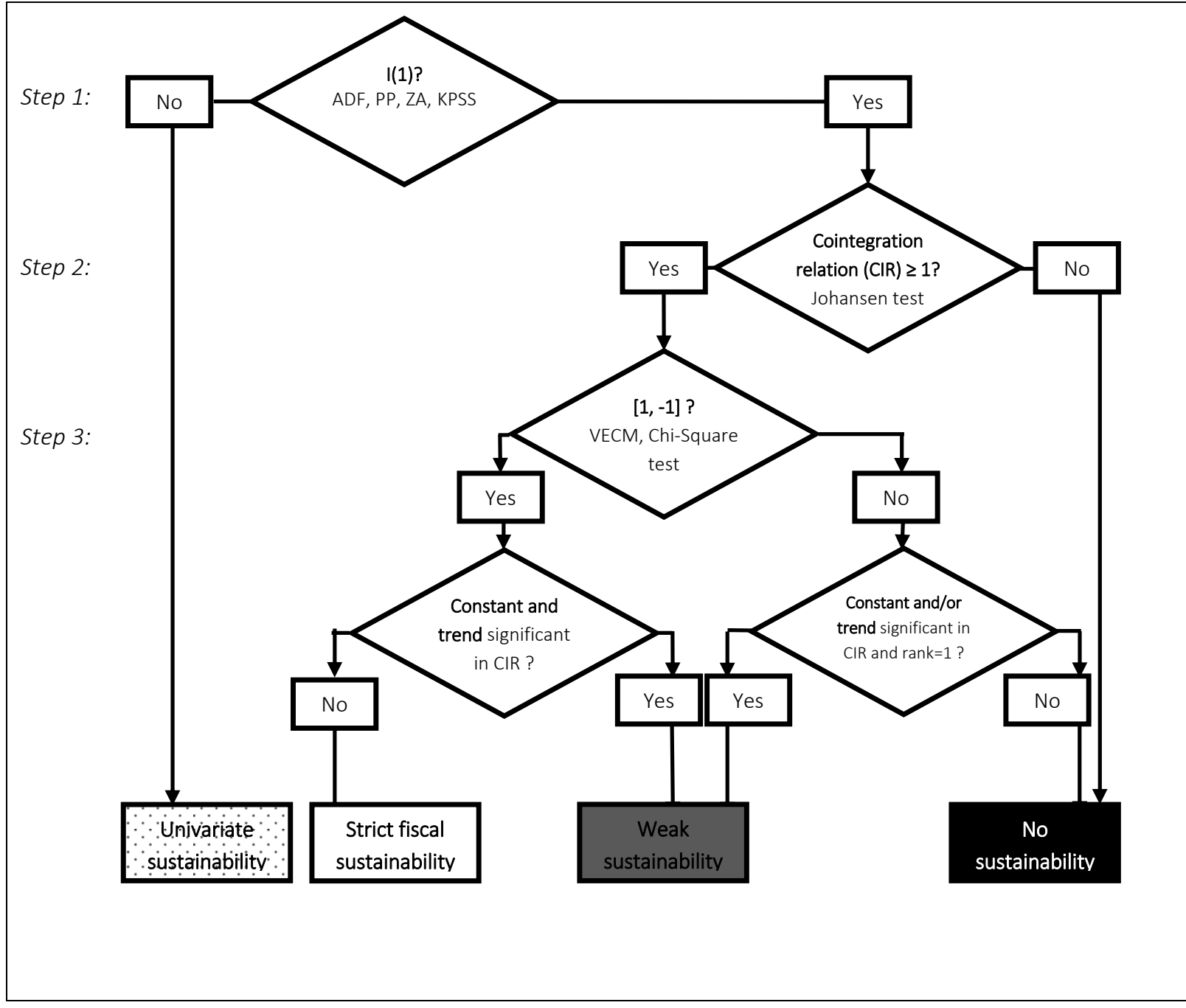

In a first step we analyze the stationarity properties of the time series on public debt, expenditures and revenues in each Land using the Augmented Dickey Fuller (ADF), the Philipps-Perron (PP) and the Kwiatkowski (KPSS) test. While the ADF and PP tests examine the null hypothesis of a unit root in time series analysis, the KPSS test has the null of a trend stationary time series. ${ }^{4}$ The tests are applied in levels and in first differences, respectively. However, structural breaks in the time series might be present due to multiple business cycles and fiscal reforms since 1950. These structural breaks can decrease the power of a standard

\footnotetext{
4 The ADF test determines the number of lags using the Hannan-Quinn criterion, the PP test selects the bandwidth automatically in accordance to the Newey-West procedure using Bartlett kernel (Newey and West 1994), and the KPSS test with equivalent bandwidth selection procedures (Hamilton 1994). See also Campbell and Perron (1991) and Cheung and Lai (1995) for the application of unit-root tests on (fiscal) macro data.
} 
unit root test by, for example, making the ADF-test biased towards a non-rejection of the null hypothesis. To overcome this shortcoming and to control for structural breaks, we follow a twofold approach: First, we conduct the unit root and stationarity tests on each Land allowing for different trend and intercept assumptions; second we allow for structural breaks in the time series by additionally applying a test suggested by Zivot and Andrews (ZA). The test examines the null hypothesis of a unit root against the break-stationarity alternative and chooses the break date where the t-statistics from the ADF test is most negative, i.e., the evidence is "least favorable for the unit root null" (Glynn et al. 2007: 68). The ZA test is applied in levels allowing for a structural break in the intercept and in the intercept and trend, respectively. ${ }^{5}$

In a second step, Johansen cointegration tests are performed to test for cointegration between expenditure and revenue in each Land. The lag lengths are selected in accordance with the results of 16 Vector Autoregression (VAR) models which are estimated step by step. The application of the Johansen cointegration test requires subtracting one lag length since it is estimated in first differences. Applying two variables does not provide any problem, as the minimum number of variables for a Johansen procedure is two. This is followed by the estimation of Vector Error Correction Models (VECM) allowing for multiple assumptions such as a trend in the data, a constant in the error correction term and a trend in the cointegration relation, respectively.

If we find indications for a cointegration relation, we examine the cointegration vector in a third step. According to Afonso (2005) fiscal policy is sustainable, if the time series of expenditures and revenues are cointegrated and the hypothesis of a "normality vector" of [1,1] holds. Conversely, if a cointegration relation of $[1,-1]$ can be rejected, fiscal policy is unsustainable. Thus, our main objective is to test whether a one-percentage point increase in revenues leads to a one-percentage point increase in expenditures (and vice versa). To investigate that matter we follow recent contributions and conduct Chi-Square tests (e.g., Kirchgässner and Prohl 2008).

\footnotetext{
5 The Akaike Information Criterion (AIC) is used to determine the optimal number of lags. We allow for a maximum of four lags which corresponds to the VAR lag length criteria on each variable in any Land under consideration.
} 
Koester and Priesmeier (2013) show that a significant constant in the error correction term is associated with fiscal unsustainability because it implies a wedge between revenues and expenditures. This contributes to the increase of deficits, especially if the time range extends across multiple decades. In addition, Koester and Priesmeier (2013) suggest that a significant trend in the error correction term can be interpreted as an increasing wedge between revenues and expenditures across time. We are, however, more reluctant with this economic interpretation. For us, evidence for a long-run relation of expenditures and revenues (i.e. cointegration rank $=1$ ) in combination with at least one significant element in the long-run relation (constant and/or trend) is an indication for weak fiscal sustainability: Any econometric evidence that is in support for a unique and significant long-run relationship is therefore granted in favor of fiscal sustainability. To make this clearer, suppose a relationship between revenues and expenditures (even with an increasing wedge) can be found. This would imply empirical evidence for a potential equilibrium that might be stabilized by political action. To determine whether at least one element in the long-run relation is significant, we conduct Chi-Square tests allowing for multiple assumptions, including a constant, a trend and a deterministic trend in the cointegration relation, respectively.

For the sake of economic interpretation, the time series results are used for inference about fiscal sustainability as follows:

- If we find conclusive evidence that public debt is stationary we have indication for strict fiscal sustainability. If the debt series is non-stationary or evidence is ambiguous, we proceed with a cointegration analysis of expenditures and revenues as shown in Figure 2.

- If no significant cointegration relation between revenues and expenditures is found in step 2, we abort our analysis and conclude that public finances are not sustainable in the corresponding Land. On the contrary, in case of a significant cointegration relation we further test in step 3 whether a cointegration vector of $[1,-1]$ exists. If the presence of such a vector is rejected and the constant and/or trend in the error correct term are not significant we do not have any indication for a significant long-run relation and, thus, conclude that public finances are not sustainable. If the constant and/or trend is, however, significant we conclude that public finances are weakly sustainable. 
The same conclusion is drawn in case of a cointegration vector of $[1,-1]$ and a significant trend and constant. Strict sustainability is only concluded if we find a cointegration vector of $[1,-1]$ and an insignificant constant and trend in the error correct term.

The stationarity characteristics of public debt are supplementarily used to further differentiate between the three groups of Laender (not sustainable, weakly sustainable, strictly sustainable).

\section{Empirical Results}

For reasons of clarity and comprehensibility the discussion of our findings is primarily focused on Baden-Wuerttemberg, Bavaria, Hesse, North Rhine-Westphalia and Rhineland-Palatinate. These five Laender are chosen due to their economic meaning, population size, status within the fiscal equalization scheme and fiscal stance. We try to group the remaining eleven Laender to one of these five examples if the time series characteristics are similar. Finally, the main results are briefly summarized for each Land in a last step. The detailed test results for the remaining Laender are provided in the Appendix.

\subsection{Baden-Wuerttemberg (BW)}

\section{Step 1: Unit root and stationarity tests, BW (Table 1, upper panel)}

The ADF and PP tests jointly suggest that public debt has a unit root in levels and no unit root in first differences. The KPSS confirms the findings in levels but not in first differences. Similarly, the ZA test cannot reject the null hypothesis of a unit root in the time series with a structural break in the intercept. The test indicates a break point in the year of 1968 which corresponds with the last year before the German fiscal constitution, in particular Article 115 German Basic Law (Grundgesetz), was reformed. The same break point is reported for the general public debt series in the period 1950-2010 (Burret et al. 2013). Similar to Herzog (2010), we conclude that public debt in Baden-Wuerttemberg is not stationary and, thus, not sustainable across time.

Regarding revenues the results are trend-sensitive: Unit roots in levels are not rejected at a significance level below $10 \%$ by any test result if trend assumptions are respected. However, if we only assume a constant, stationarity is indicated by all tests. For expenditures, the results are inconclusive: The ADF and PP tests jointly suggest that the time series is non-stationary in 
levels. While the KPSS test confirms the finding if a trend is included, the null hypothesis of no unit root cannot be rejected otherwise. Moreover, both ZA breakpoint tests reject stationarity of the time series at the $5 \%$ level.

\section{Step 2: Cointegration of revenue and expenditure, BW (Table 1, middle panel)}

In order to determine the number of cointegration relations in the system, we perform Johansen tests on cointegration between revenue and expenditure. To do so, we retrieve the lag length criteria from a VAR, whereas the Akaike Information Criterion (AIC) suggests a lag length of 1 . If we assume no trend in the series, the Trace and Maximum Eigenvalue tests jointly reject the null of no cointegration at the $5 \%$ significance level and imply one cointegration vector at the same significance level. While the Maximum Eigenvalue test confirms this finding if we assume a trend in the data and allow for intercept and trend in the cointegration relation, the null of no cointegration is retained by the Trace test. Cheung and Lai (1995) show that the Trace test is more robust than the Maximum Eigenvalue test regarding skewness and excess kurtosis of residuals. Thus, we conclude that no cointegration exists if a trend in the cointegration relation is assumed. However, to double check Cheung and Lai (1995) we subsequently test on the sustainability vector of $[1,-1]$.

\section{Step 3: Test on cointegration vector $[1,-1]$ and statistical inference, BW (Table 1, lower panel)}

To test whether one percentage point increase in revenues leads to a one percentage point increase in expenditures (and vice versa) we analyze whether the cointegrating vector of rank 1 is $[1,-1]$ by estimating VECM models. The VAR suggests a lag length of 0 for the VECM of the cointegrated time series. The Chi-Square test rejects the null hypothesis that the cointegrating vector is $[1,-1]$ at the $1 \%$ significance level. This finding is robust to the inclusion of a trend in the cointegration relation. The significant intercept in the error correction indicates that a constant wedge between revenues and expenditures exists which might contribute to deficits across time (Koester and Priesmeier, 2013). Although revenues and expenditures are cointegrated, public finances in Baden-Wuerttemberg do not meet the conditions for strict fiscal sustainability, i.e. a cointegrating vector of $[1,-1]$. However, the significant cointegration indicates signs of weak fiscal sustainability. Due to similar time series properties, a similar conclusion is drawn for Brandenburg (Table A.10), Hesse (Table 3), Lower-Saxony (Table A.13), North-Rhine Westphalia (Table 4) and Schleswig-Holstein (Table 
A.18). However, it has to be noted that we do not have clear indication that public debt follows a non-stationary process in Hesse, Lower Saxony and Brandenburg.

Table 1 Baden-Wuerttemberg

Step 1: Unit root and stationary tests

\begin{tabular}{|c|c|c|c|c|c|}
\hline & & & Debt & Expenditure & Revenue \\
\hline \multirow[t]{3}{*}{ ADF } & \multirow{2}{*}{ Level } & Constant & 0.979 & -2.540 & $-3.310 * *$ \\
\hline & & Constant and trend & -2.422 & -2.560 & $-3.280^{*}$ \\
\hline & $1^{\text {st }}$ differences & Constant & $-7.610 * * *$ & $-8.970 * * *$ & $-8.832 * * *$ \\
\hline \multirow[t]{3}{*}{ PP } & \multirow{2}{*}{ Level } & Constant & 0.998 & -2.473 & $-3.250 * *$ \\
\hline & & Constant and trend & -2.370 & -2.542 & $-3.228^{*}$ \\
\hline & $1^{\text {st }}$ differences & Constant & $-6.980 * *$ & $-9.219 * * *$ & $-13.373 * * *$ \\
\hline \multirow[t]{3}{*}{ KPSS } & \multirow{2}{*}{ Level } & Constant & $0.805^{* * *}$ & 0.265 & 0.197 \\
\hline & & Constant and trend & $0.156^{* *}$ & $0.222 * * *$ & $0.197 * *$ \\
\hline & $1^{\text {st }}$ differences & Constant & $0.463^{* *}$ & 0.067 & 0.315 \\
\hline \multirow[t]{2}{*}{ ZA } & \multirow{2}{*}{ Level } & Constant & $-2.823(1968)$ & $-4.072 * *(1997)$ & $-4.509 *(1997)$ \\
\hline & & Constant and trend & n.s.m. & $-5.329 * *(1974)$ & $-4.557(1976)$ \\
\hline \multicolumn{3}{|l|}{ Verdict } & non-stationary & inconclusive & inconclusive \\
\hline
\end{tabular}

\section{Step 2: Johansen test on cointegration between expenditure and revenue}

\begin{tabular}{lccc}
\hline Constant & & & \\
Null hypothesis & Eigenvalue & Trace statistic & 5\% critical value \\
\hline None & 0.256 & $23.297^{* *}$ & 20.262 \\
At most1 & 0.089 & 5.562 & 9.165 \\
& & \multicolumn{2}{c}{ Max. Eigenvalue statistic } \\
\hline 0 & 0.256 & $17.735^{* *}$ & 15.892 \\
1 & 0.089 & 5.562 & 9.165
\end{tabular}

\begin{tabular}{lccc}
\hline $\begin{array}{l}\text { Constant and trend } \\
\text { Null hypothesis }\end{array}$ & Eigenvalue & Trace statistic & 5\% critical value \\
\hline None & 0.279 & 25.154 & 25.872 \\
At most 1 & 0.088 & 5.553 & 12.518 \\
& & \multicolumn{2}{c}{ Max. Eigenvalue statistic } \\
\hline 0 & 0.279 & $19.601^{* *}$ & 19.387 \\
1 & 0.088 & 5.553 & 12.518
\end{tabular}

Note: The Johansen test examines the hypothesized number of cointegration relations, i.e. the rank of the matrix ( $r$ ). The number of cointegration relations is smaller than 1, i.e., "None", following Trace test's null hypothesis. If the statistic is higher than the critical value, the null hypothesis is rejected. Eigenvalue test examines the null that the number of cointegration relations ( $r$ ) is " 0 ". The critical values for both tests are derived from the Trace and Maximum Eigenvalue of the stochastic matrix. '***', '**' and '*' indicate that the corresponding null hypothesis can be rejected at the $1 \%, 5 \%$, and $10 \%$ significance level, respectively.

Step 3: Test on sustainability vector $[1,-1]$ in cointegration relation between expenditures and revenues

\begin{tabular}{ccccc}
\hline $\begin{array}{l}\text { Constant } \\
\text { Chi-Square }\end{array}$ & Prob. & Rev. & Exp. & Constant \\
\hline $6.767^{* * *}$ & 0.010 & 1.000 & -1.000 & 0.004 \\
& & & & $(0.001)$ \\
& & & & {$[2.711]$}
\end{tabular}

\begin{tabular}{cccccc}
\hline \multicolumn{2}{c}{ Constant and trend } & & & & \\
Chi-Square & Prob. & Rev. & Exp. & Constant & Trend \\
\hline $7.370^{* * *}$ & 0.006 & 1.000 & -1.000 & 0.001 & 0.056 \\
& & & & & $(0.047)$ \\
& & & & {$[1.183]$}
\end{tabular}

Note: The Chi-Square test has the null that the cointegration vector is $[1,-1]$. The estimated variance is indicated in parentheses and the $t-$ statistic is indicated in brackets. ' $* * *$ ', '**' and '*' indicate that the corresponding null hypothesis can be rejected at the $1 \%, 5 \%$, and $10 \%$ significance level, respectively.

\subsection{Bavaria (BY)}

\section{Step 1: Unit root and stationarity tests, BY (Table 2, upper panel)}

Since public debt in Bavaria is at low levels compared to other Laender we expect Bavaria to show relatively sound finances. While the ADF, PP and KPSS tests jointly reject a unit root in the time series if we allow for an exogenous trend, it is retained otherwise. The ZA test indicates a structural break in the intercept in 1978 - shortly after a near-continuous debt decrease lasting almost two decades came to an end. Regarding revenues and expenditures, 
unit roots in levels is not rejected at a significance level below $10 \%$ by any test results except for expenditures in the ZA test with a break in the intercept and trend. In sum, public debt in Bavaria is stationary once we allow for a trend, while expenditures and revenues are I(1).

\section{Step 2: Cointegration of revenue and expenditure, BY (Table 2, middle panel)}

The hypothesis of no cointegration is conclusively rejected by the Trace and the Maximum Eigenvalue test at the $1 \%$ significance level. This holds for both specifications: with a constant in the error correction and with a constant and trend in the cointegration relation. All four tests indicate one cointegration relation.

\section{Step 3: Test on cointegration vector $[1,-1]$ and statistical inference, BY (Table 2, lower panel)}

The VAR suggests a lag length of zero for the VECM of the cointegrated time series. While the null hypothesis of a cointegrating vector $[1,-1]$ is retained by the Chi-Square test if we allow for a constant in the cointegration relation, it is rejected at the $1 \%$ significance level once a trend is added. Thus, sustainability of fiscal policy could be doubted if we allowed for a trend in the cointegration relation. However, the trend does not reach statistical significance in the error correction model, which indicates that the wedge between expenditures and revenues is at least not increasing across time. Given the significant cointegration of revenues and expenditures and the cointegration vector of $[1,-1]$ without a trend, we have at least some evidence for strict sustainability in Bavaria. Due to similar time series properties, a similar conclusion is drawn for Hamburg (Table A.12) despite the fact that public debt in Hamburg does not follow a stationary process (neither with nor without a trend). Moreover, Hamburg has a significant trend in the cointegration relation. Therefore the indication for strict sustainability is more pronounced in the case of Bavaria.

Table 2 Bavaria

Step 1: Unit root and stationary tests

\begin{tabular}{|c|c|c|c|c|c|}
\hline & & & Debt & Expenditure & Revenue \\
\hline \multirow[t]{3}{*}{ ADF } & \multirow{2}{*}{ Level } & Constant & 2.029 & -2.286 & -2.247 \\
\hline & & Constant and trend & $-3.754^{* *}$ & -3.013 & $-3.283^{*}$ \\
\hline & $1^{\text {st }}$ differences & Constant & $-4.496 * * *$ & $-7.692^{* * *}$ & $-7.066^{* * *}$ \\
\hline \multirow[t]{3}{*}{ PP } & \multirow{2}{*}{ Level } & Constant & -2.258 & -2.094 & -1.905 \\
\hline & & Constant and trend & $-3.710^{* *}$ & -3.077 & $-3.245^{*}$ \\
\hline & $1^{\text {st }}$ differences & Constant & $-4.488 * * *$ & $-11.632 * * *$ & $-18.937 * * *$ \\
\hline \multirow[t]{3}{*}{ KPSS } & \multirow{2}{*}{ Level } & Constant & $0.360 *$ & $0.606 * *$ & $0.673^{* *}$ \\
\hline & & Constant and trend & 0.119 & $0.207^{* *}$ & $0.198 * *$ \\
\hline & $1^{\text {st }}$ differences & Constant & $0.396^{*}$ & 0.152 & 0.297 \\
\hline \multirow[t]{2}{*}{ ZA } & \multirow{2}{*}{ Level } & Constant & $-4.494(1978)$ & $-4.165(1962)$ & $-4.652 *(1963)$ \\
\hline & & Constant and trend & n.s.m. & $-5.366 * *(1983)$ & $-5.064 *(1972)$ \\
\hline Verdict & & & inconclusive & non-stationary & non-stationary \\
\hline
\end{tabular}


Step 2: Johansen test on cointegration between expenditure and revenue

\begin{tabular}{lccc}
\hline Constant \\
Null hypothesis & Eigenvalue & Trace statistic & 5\% critical value \\
\hline None & 0.397 & $34.738^{* * *}$ & 20.261 \\
At most1 & 0.071 & 4.412 & 9.165 \\
& & \multicolumn{2}{c}{ Max. Eigenvalue statistic } \\
\hline 0 & 0.397 & $30.326^{* * *}$ & 15.892 \\
1 & 0.071 & 4.412 & 9.165
\end{tabular}

\begin{tabular}{|c|c|c|c|}
\hline \multicolumn{4}{|l|}{ Constant and trend } \\
\hline Null hypothesis & Eigenvalue & Trace statistic & $5 \%$ critical value \\
\hline None & 0.402 & $38.188^{* * *}$ & 25.872 \\
\hline \multirow[t]{2}{*}{ At most 1} & 0.115 & 7.344 & 12.518 \\
\hline & & \multicolumn{2}{|c|}{ Max. Eigenvalue statistic } \\
\hline 0 & 0.402 & $30.844 * * *$ & 19.387 \\
\hline 1 & 0.115 & 7.344 & 12.518 \\
\hline
\end{tabular}

Step 3: Test on sustainability vector $[1,-1]$ in cointegration relation between expenditures and revenues

\begin{tabular}{rcccc}
\hline $\begin{array}{l}\text { Constant } \\
\text { Chi-Square }\end{array}$ & Prob. & Rev. & Exp. & Constant \\
\hline 2.928 & 0.087 & 1.000 & -1.000 & 0.002
\end{tabular}

\begin{tabular}{cccccc}
\hline \multicolumn{2}{l}{ Constant and trend } & & & & \\
Chi-Square & Prob. & Rev. & Exp. & Constant & Trend \\
\hline $5.203^{* * *}$ & 0.021 & 1.000 & -1.000 & 0.000 & 0.050 \\
& & & & & $(0.034)$ \\
& & & & & {$[1.461]$}
\end{tabular}

For notes see Table 1.

\subsection{Hesse (HE)}

\section{Step 1: Unit root and stationarity tests, HE (Table 3, upper panel)}

The unit root and stationarity test results for public debt are trend-sensitive: ADF, PP and KPSS jointly indicate non-stationarity in debt levels if we do not allow for a trend and stationarity otherwise. The ZA test rejects the hypothesis that debt has a unit root with a structural break in the intercept in the year 1978 - shortly after the sharp debt increase of the mid-1970s came to an end. Regarding expenditures in levels all tests indicate I(1) except for the ZA test with a trend. The results for revenues are ambiguous. While the ADF, PP and KPSS test jointly indicate stationarity if we allow for an exogenous trend, the ZA test, again allowing for a trend, strongly rejects a unit root. If the trend assumption is not applied, we have indication for non-stationarity.

\section{Step 2: Cointegration of revenue and expenditure, HE (Table 3, middle panel)}

We can reject the hypothesis of no cointegration relation between expenditures and revenues at least at the 5\% significance level according to both the Trace and the Maximum Eigenvalue test with and without a trend in the series. The tests jointly indicate one cointegration relation.

\section{Step 3: Test on cointegration vector $[1,-1]$ and statistical inference, HE (Table 3, lower panel)}

The VAR suggests a lag length of zero for the VECM of the cointegrated time series. Allowing for a constant in the cointegration relation, the null hypothesis that the cointegrating vector is $[1,-1]$ is rejected at the $1 \%$ level by the Chi-Square test. Similar results are obtained if we allow for a trend in the cointegration relation. The significant trend in the error correction 
term indicates that the wedge between expenditures and revenues is increasing across time. Therefore, we conclude that revenues and expenditures in Hesse are cointegrated, but do not follow a sustainable path since 1950 , i.e. the cointegration vector of $[1,-1]$ is rejected. This means that there is some evidence that Hesse is only weakly sustainable. Due to similar time series properties, this conclusion can be drawn for Baden-Wuerttemberg (Table 1), Lower Saxony (Table A.13), North Rhine-Westphalia (Table 4), Schleswig-Holstein (Table A.18) and Brandenburg (Table A.10). Nevertheless it should be noted that stationarity of public debt is only indicated for Hesse (once a trend is included).

Table 3 Hessen

Step 1: Unit root and stationary tests

\begin{tabular}{|c|c|c|c|c|c|}
\hline & & & Debt & Expenditure & Revenue \\
\hline \multirow[t]{3}{*}{ ADF } & \multirow{2}{*}{ Level } & Constant & 1.040 & -2.129 & $-3.040 * *$ \\
\hline & & Constant and trend & $-4.588 * * *$ & -2.155 & -2.988 \\
\hline & $1^{\text {st }}$ differences & Constant & $-4.533 * * *$ & $-8.008 * * *$ & $-7.065 * * *$ \\
\hline \multirow[t]{3}{*}{ PP } & \multirow{2}{*}{ Level } & Constant & 0.700 & -2.053 & $-2.771^{*}$ \\
\hline & & Constant and trend & $-3.863 * *$ & -2.133 & -2.781 \\
\hline & $1^{\text {st }}$ differences & Constant & $-4.727 * * *$ & $-8.068 * * *$ & $-10.161^{* * *}$ \\
\hline \multirow[t]{3}{*}{ KPSS } & \multirow{2}{*}{ Level } & Constant & $0.864 * * *$ & $0.392 * *$ & 0.191 \\
\hline & & Constant and trend & 0.095 & $0.194 * *$ & $0.134 *$ \\
\hline & $1^{\text {st }}$ differences & Constant & $0.325 *$ & 0.104 & $0.500 * *$ \\
\hline \multirow[t]{2}{*}{ ZA } & \multirow{2}{*}{ Level } & Constant & $-5.361 * * *(1975)$ & $-4.165(1960)$ & n.s.m. \\
\hline & & Constant and trend & n.s.m. & $-5.117 * *(1961)$ & $-6.456 * * *(1972)$ \\
\hline Verdic & & & inconclusive & non-stationary & inconclusive \\
\hline
\end{tabular}

Step 2: Johansen test on cointegration between expenditure and revenue

\begin{tabular}{lccc}
\hline $\begin{array}{l}\text { Constant } \\
\text { Null hypothesis }\end{array}$ & Eigenvalue & Trace statistic & 5\% critical value \\
\hline None & 0.270 & $25.403^{* * *}$ & 20.261 \\
At most1 & 0.097 & 6.191 & 9.165 \\
& & \multicolumn{2}{c}{ Max. Eigenvalue statistic } \\
0 & 0.270 & $19.212^{* * *}$ & 15.892 \\
1 & 0.097 & 6.191 & 9.165
\end{tabular}

\begin{tabular}{lccc}
\hline $\begin{array}{l}\text { Constant and trend } \\
\text { Null hypothesis }\end{array}$ & \multicolumn{3}{c}{ Eigenvalue } \\
None & 0.292 & $28.717^{* * *}$ & 25.872 \\
At most 1 & 0.118 & 7.652 & 12.518 \\
& & Max. Eigenvalue statistic \\
0 & 0.292 & $21.065^{* * *}$ & 19.387 \\
1 & 0.118 & 7.652 & 12.518
\end{tabular}

Step 3: Test on sustainability vector $[1,-1]$ in cointegration relation between expenditures and revenues

\begin{tabular}{ccccc}
\hline Constant & & & & \\
Chi-Square & Prob. & Rev. & Exp. & Constant \\
\hline $7.755^{* * *}$ & 0.005 & 1.000 & -1.000 & 0.005 \\
& & & & $(0.002)$ \\
& & & & {$[3.516]$}
\end{tabular}

\begin{tabular}{cccccc}
\hline \multicolumn{2}{l}{ Constant and trend } & & & & \\
Chi-Square & Prob. & Rev. & Exp. & Constant & Trend \\
\hline $4.523^{* *}$ & 0.033 & 1.000 & -1.000 & -0.0267 & 0.000 \\
& & & & & $(0.044)$
\end{tabular}

For notes see Table 1.

\subsection{North Rhine-Westphalia (NW)}

\section{Step 1: Unit root and stationarity tests, NW (Table 4, upper panel)}

The unit root and stationarity tests clearly indicate that public debt in North Rhine-Westphalia is I(1). Thus, we have conclusive evidence that public debt is not sustainable. For expenditures and revenues the results are inconclusive: expenditures are I(1) according to any trend 
adjusted test. However, the ADF and PP tests reject non-stationarity if no trend is assumed. Regarding revenues the tests are inconclusive. The ADF and ZA tests indicate I(1), while the PP tests rejects a unit root in the time series. Furthermore, the KPSS test suggests stationarity if a trend is included and non-stationarity otherwise. Thus, time series properties of revenues and expenditures are further analyzed in the next step.

\section{Step 2: Cointegration of revenue and expenditure, NW (Table 4, middle panel)}

The Trace and Maximum Eigenvalue test both reject the null of no cointegration between revenues and expenditures at the 5\% significance level with or without a trend in the cointegration relation. The test results indicate one cointegration relationship in both cases.

\section{Step 3: Test on cointegration vector $[1,-1]$ and statistical inference, NW (Table 4, lower panel)}

The VAR suggests a lag length of zero for the VECM of the cointegrated time series. Allowing for a constant and a constant and trend in the cointegration relation the null hypothesis of a cointegrating vector of $[1,-1]$ is rejected at the $1 \%$ significance level. Furthermore, the constant and the trend are both significant in the error correction term. This implies a constant wedge between expenditures and revenues leading to increasing debt levels. In sum, we find a significant cointegration of revenues and expenditures in North RhineWestphalia but reject a cointegration vector of $[1,-1]$. Thus, fiscal policy in North RhineWestphalia is at best associated with weak sustainability. Due to similar time series properties, a similar conclusion can be drawn for Baden-Wuerttemberg (Table 1), Brandenburg (Table A.10), Hesse (Table 3), Lower Saxony (Table A.13) and Schleswig-Holstein (Table A.18). Note, stationarity of public debt is only conclusively rejected in North RhineWestphalia, Baden-Wuerttemberg and Schleswig-Holstein.

Table $4 \quad$ North Rhine-Westphalia

Step 1: Unit root and stationary tests

\begin{tabular}{|c|c|c|c|c|c|}
\hline & & & Debt & Expenditure & Revenue \\
\hline \multirow[t]{3}{*}{ ADF } & \multirow{2}{*}{ Level } & Constant & 1.981 & $-2.771^{*}$ & -1.981 \\
\hline & & Constant and trend & -2.090 & -2.710 & $-3.479 *$ \\
\hline & $1^{\text {st }}$ differences & Constant & $-4.428 * * *$ & $-7.338^{* * *}$ & $-7.681^{* * *}$ \\
\hline \multirow[t]{3}{*}{ PP } & \multirow{2}{*}{ Level } & Constant & 1.749 & $-3.003 * *$ & $-3.003 * *$ \\
\hline & & Constant and trend & -1.712 & $-3.529 * *$ & $-3.529 * *$ \\
\hline & $1^{\text {st }}$ differences & Constant & $-5.428 * * *$ & $-7.583^{* * *}$ & $-7.583^{* * *}$ \\
\hline \multirow[t]{3}{*}{ KPSS } & \multirow{2}{*}{ Level } & Constant & $0.856 * * *$ & $0.679 * *$ & $0.679 * *$ \\
\hline & & Constant and trend & $0.137^{*}$ & 0.047 & 0.047 \\
\hline & $1^{\text {st }}$ differences & Constant & $0.326^{*}$ & 0.157 & 0.157 \\
\hline \multirow[t]{2}{*}{ ZA } & \multirow{2}{*}{ Level } & Constant & $-2.341(1980)$ & $-4.099(1973)$ & $-3.729(2001)$ \\
\hline & & Constant and trend & n.s.m. & $-4.105(1973)$ & $-3.997(1972)$ \\
\hline
\end{tabular}


Step 2: Johansen test on cointegration between expenditure and revenue

\begin{tabular}{lccc}
\hline $\begin{array}{l}\text { Constant } \\
\text { Null hypothesis }\end{array}$ & Eigenvalue & Trace statistic & 5\% critical value \\
\hline None & 0.242 & $23.032^{* *}$ & 20.261 \\
At most1 & 0.094 & 6.001 & 9.165 \\
& & Max. Eigenvalue statistic \\
\hline 0 & 0.242 & $17.031^{* *}$ & 15.892 \\
1 & 0.094 & 6.001 & 9.165
\end{tabular}

\begin{tabular}{|c|c|c|c|}
\hline \multicolumn{4}{|c|}{ Constant and trend } \\
\hline Null hypothesis & Eigenvalue & Trace statistic & $5 \%$ critical value \\
\hline None & 0.318 & $32.155^{* * *}$ & 25.872 \\
\hline \multirow[t]{2}{*}{ At most 1} & 0.134 & 8.793 & 12.518 \\
\hline & & \multicolumn{2}{|c|}{ Max. Eigenvalue statistic } \\
\hline 0 & 0.318 & $23.362 * * *$ & 19.387 \\
\hline 1 & 0.134 & 8.793 & 12.518 \\
\hline
\end{tabular}

Step 3: Test on sustainability vector $[1,-1]$ in cointegration relation between expenditures and revenues

\begin{tabular}{lcccc}
\hline Constant & & & & \\
Chi-Square & Prob. & Rev. & Exp. & Constant \\
\hline $10.785^{* * *}$ & 0.001 & 1.000 & -1.000 & 0.006 \\
& & & & $0.002)$ \\
& & & & {$[2.335]$}
\end{tabular}

\begin{tabular}{cccccc}
\hline \multicolumn{2}{c}{ Constant and trend } & & & & \\
Chi-Square & Prob. & Rev. & Exp. & Constant & Trend \\
\hline $13.508^{* * *}$ & 0.000 & 1.000 & -1.000 & -0.001 & 0.000 \\
& & & & & $(0.066)$ \\
& & & & & {$[2.381]$}
\end{tabular}

For notes see Table 1.

\subsection{Rhineland-Palatinate (RP)}

\section{Step 1: Unit root and stationarity tests, RP (Table 5, upper panel)}

The ADF and PP tests retain non-stationarity of public debt in Rhineland-Palatinate without a trend and reject non-stationary with a trend (however only at the 10\% level). The KPSS tests support these results. The ZA test results reject a random walk in public debt if no trend is assumed and reveals a break point in 1989, one of the few years in which the debt-to-GDP ratio decreased. In sum, we have evidence that public debt in Rhineland-Palatinate is I(1). Regarding public expenditures the tests clearly indicate I(1). Similarly, the results for revenues indicate non-stationarity of the time series. The ADF, PP and ZA tests do not reject the presence of a unit root. The findings of the KPSS test are, however, trend sensitive. Thus, the time series properties of revenues and expenditures are further analyzed in a cointegration analysis.

\section{Step 2: Cointegration of revenue and expenditure, RP (Table 5, middle panel)}

We have estimated five cointegration tests with the following specifications. The first two tests assume no trend in the data and differ with respect to the assumption of an intercept in the cointegration relation: Both reject cointegration between revenues and expenditures. The second pair of tests assumes a linear trend in the data and an intercept in the cointegration relation. It also differs with respect to the inclusion of a trend component in the cointegration relation. This second pair of tests rejects cointegration over the same lag interval. The fifth test assumes a quadratic trend in the data, an intercept and trend in the cointegration relationship. Unlike the tests before, this cointegration test identifies one cointegration vector. To confirm these results, we directly test for a cointegration with 0 lags (and employ 
$\mathrm{SC}$ and $\mathrm{HQ}$ lag length criteria). As shown in Table 4, the null hypothesis of no cointegration of expenditures and revenues is rejected by the Trace test and retained by the Maximum Eigenvalue test. Despite this ambiguity, Cheung and Lai (1995) argue that the Trace test is more robust than the Maximum Eigenvalue test regarding type II errors, skewness and excess kurtosis of residuals (Cheung and Lai, 1995). Accordingly, we have weak indication for cointegration, but no significant evidence. Note that we have obtained similar results for Bremen.

\section{Step 3: Test on cointegration vector [1,-1] and statistical inference, RP (Table 5, lower panel)}

Since at least one out of the five conducted Johansen tests identified a cointegration vector, it has to be assessed whether revenues and expenditures are cointegrated with a $[1,-1]$ vector. First, the Chi-Square tests reject such a vector at the $10 \%$ level. Second, public debt is I(1) and third, only one out of ten Johansen tests indicates a cointegration relation between expenditure and revenue. This is evidence against a significant cointegration of rank one. Thus, fiscal policy in Rhineland-Palatinate is not sustainable. Due to similar time series properties, similar conclusions are drawn for Bremen (Table A.9), Mecklenburg-Western Pomerania (Table A.14), Saarland (Table A.15), Saxony-Anhalt (Table A.17) and Thuringia (Table A.19). However, non-stationarity of public debt is only indicated for RhinelandPalatinate, Mecklenburg-Western Pomerania and Saarland.

Table 5 Rhineland-Palatinate

Step 1: Unit root and stationary tests

\begin{tabular}{|c|c|c|c|c|c|}
\hline & & & Debt & Expenditure & Revenue \\
\hline \multirow[t]{3}{*}{ ADF } & \multirow{2}{*}{ Level } & Constant & 1.621 & -2.064 & -2.561 \\
\hline & & Constant and trend & $-3.253^{*}$ & -1.739 & -2.161 \\
\hline & $1^{\text {st }}$ differences & Constant & $-4.410 * * *$ & $-7.939 * * *$ & $-7.152 * * *$ \\
\hline \multirow[t]{3}{*}{ PP } & \multirow{2}{*}{ Level } & Constant & 1.362 & $-2.070 * *$ & -2.549 \\
\hline & & Constant and trend & $-3.358 *$ & -1.755 & -2.585 \\
\hline & $1^{\text {st }}$ differences & Constant & $-5.144 * * *$ & $-7.940 * * *$ & $-7.136 * * *$ \\
\hline \multirow[t]{3}{*}{ KPSS } & \multirow{2}{*}{ Level } & Constant & $0.869 * * *$ & $0.431^{*}$ & 0.226 \\
\hline & & Constant and trend & $0.148 * *$ & $0.220 * * *$ & $0.200 * *$ \\
\hline & $1^{\text {st }}$ differences & Constant & $0.435^{*}$ & 0.203 & 0.329 \\
\hline \multirow[t]{2}{*}{ ZA } & \multirow{2}{*}{ Level } & Constant & $-4.488(1989)$ & n.s.m. & $-2.644(1997)$ \\
\hline & & Constant and trend & n.s.m. & $-3.909(1963)$ & $-4.209(1963)$ \\
\hline Verdict & & & non-stationary & non-stationary & non-stationary \\
\hline
\end{tabular}

Step 2: Johansen test on cointegration between expenditure and revenue

\begin{tabular}{|c|c|c|c|}
\hline \multicolumn{4}{|l|}{ Constant and trend } \\
\hline Null hypothesis & Eigenvalue & Trace statistic & $5 \%$ critical value \\
\hline None & 0.231 & $19.384^{* *}$ & 18.398 \\
\hline \multirow[t]{2}{*}{ At most1 } & 0.053 & 3.334 & 3.841 \\
\hline & & \multicolumn{2}{|c|}{ Max. Eigenvalue statistic } \\
\hline 0 & 0.231 & 16.046 & 17.148 \\
\hline 1 & 0.053 & 3.340 & 3.841 \\
\hline
\end{tabular}


Step 3: Test on sustainability vector $[1,-1]$ in cointegration relation between expenditures and revenues

\begin{tabular}{|c|c|c|c|c|c|}
\hline \multicolumn{6}{|c|}{ Constant and trend } \\
\hline Chi-Square & Prob. & Rev. & Exp. & Constant & Trend \\
\hline 3.559* & 0.063 & 1.000 & -1.000 & -0.032 & 0.000 \\
\hline
\end{tabular}

For notes see Table 1. For RP the ECM was estimated with a quadratic trend in the data.

\subsection{Summary}

Table 6 briefly summarizes the main results of our test procedure for each Land. In line with the general observation that public debt has been increasing across time in the German Laender, no convincing evidence that public debt is stationary in any Land could be obtained (column A). The majority of unit root and stationary tests for the individual Laender indicate that public debt is not sustainable. While stationarity characteristics are inconclusive in other cases, we have indication for stationary debt series in Bavaria and Hesse once a trend is included.

To further explore fiscal sustainability by means of cointegration between revenues and expenditures, the two variables must not be stationary. In fact, we have no conclusive evidence of a stationary time series regarding revenues and expenditures in any Land (column B and C).

While a significant cointegration relation between revenues and expenditures is revealed in eight Laender (column D), we further test whether a one percentage point increase in revenues leads to a one percentage point increase in expenditures (and vice versa). A corresponding cointegration vector of $[1,-1]$ is not rejected in Bavaria and Hamburg (column E). Thus, these two Laender are assumed to be strictly sustainable (Figure 3 ). The other six Laender are assumed to be weakly sustainable since their revenues and expenditures are cointegrated but not with a vector that is commonly associated with strict fiscal sustainability. Unlike Hamburg, Bavaria has no significant trend in its cointegration relation and is therefore assumed to be the most fiscal responsible Land (column F). In several Laender, the tests indicate that public debt is non-stationary and that revenues and expenditures are not cointegrated. These Laender are assumed to be fiscally unsustainable. Note, however, that the findings for East German Laender have to be considered with caution since time series are rather short. 
Table 6 Summary of Main Empirical Findings

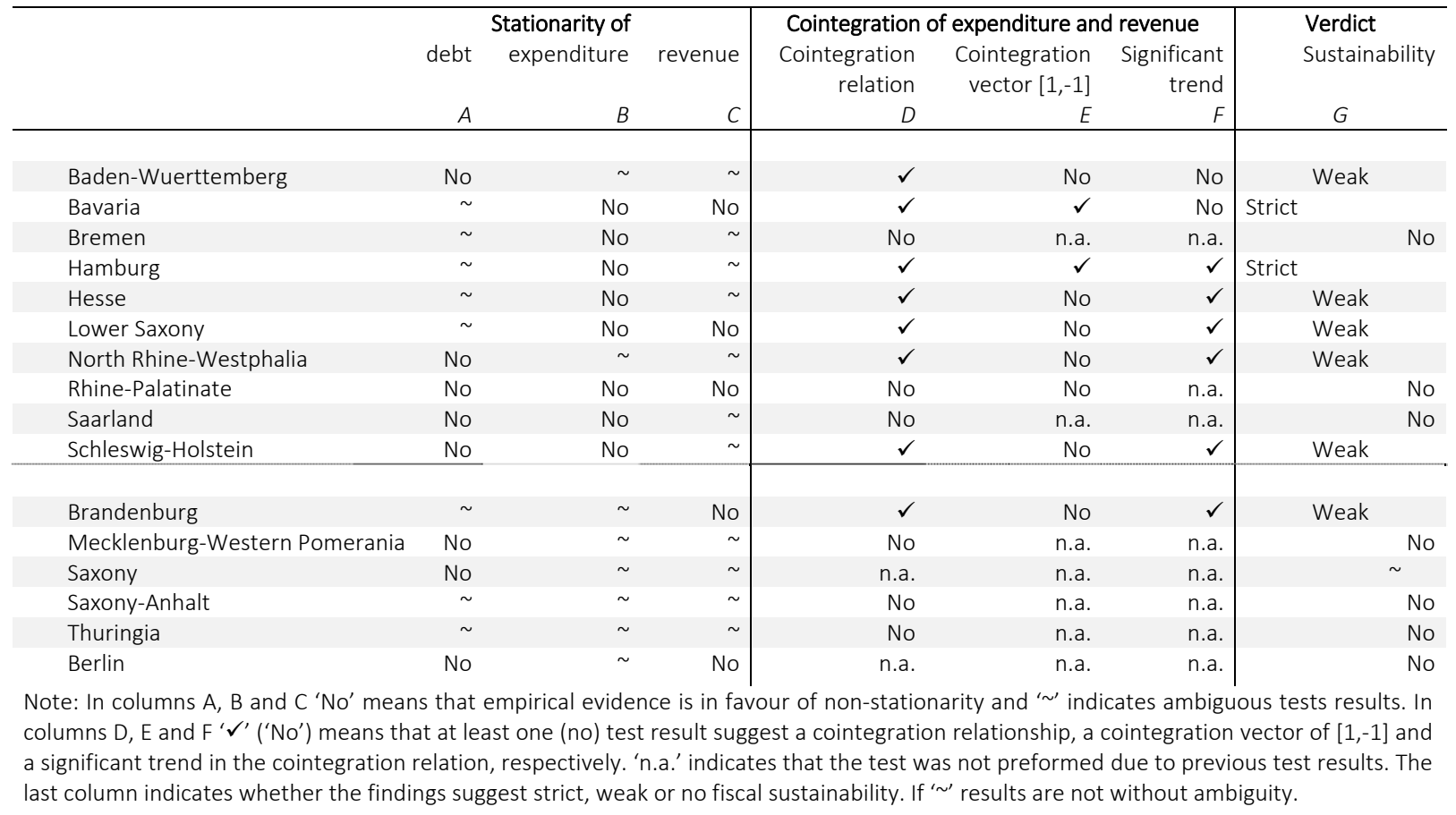

Figure 3 Fiscal Sustainability in German Laender

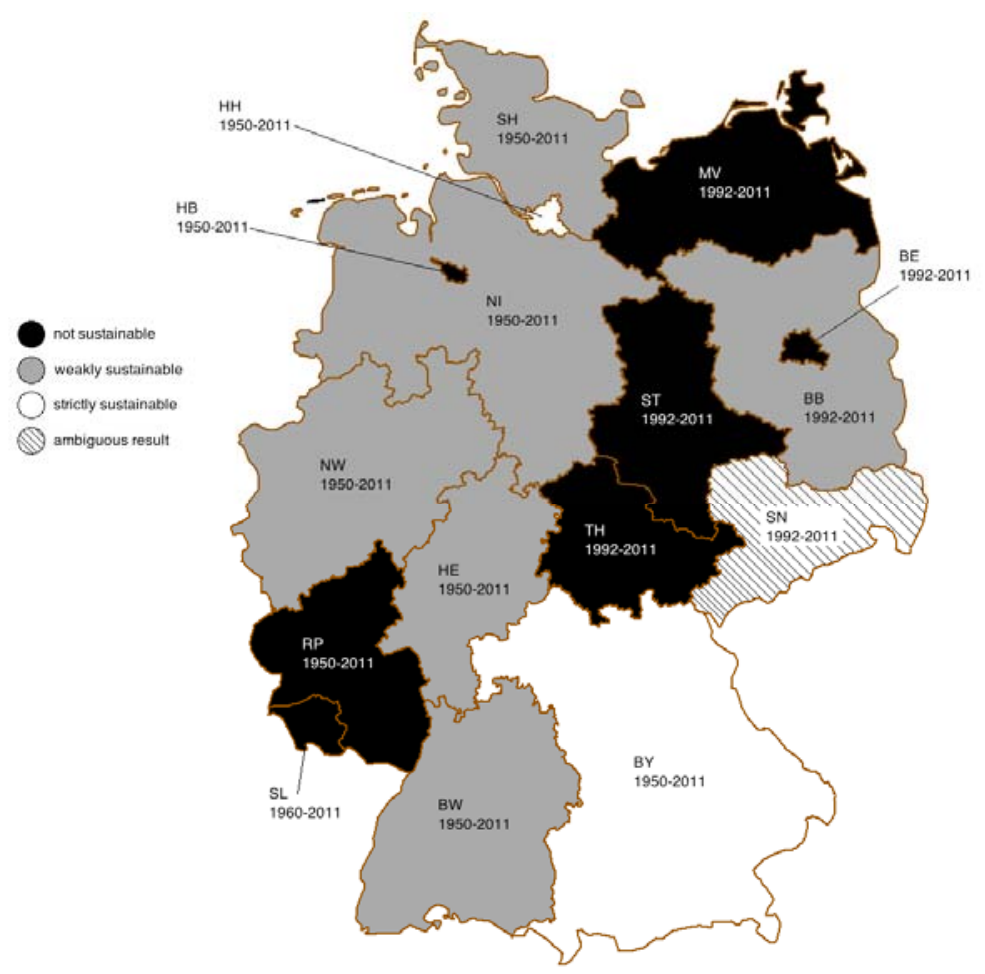

Note: The years indicates the start and end date of the time series. For abbreviation of the Laender see Figure 1.

\section{Conclusion}

Public debt is not sustainable in most of the German Laender according to our time series analysis. Against the backdrop of empirical evidence, we conclude that expenditures have 
systematically exceeded revenues in most of the German Laender over the last 60 years. A notable exception is Bavaria. Six Laender have weakly sustainable public finances. In addition to Baden-Württemberg and Hesse, North Rhine-Westphalia, Lower Saxony, SchleswigHolstein and Brandenburg are included in this group. The remaining Laender, i.e., the Saarland, Rhineland-Palatinate, Mecklenburg-Western Pomerania, Saxony-Anhalt and Thuringia, have clearly unsustainable public finances. Evidence for the East German Laender including Berlin have to be taken with caution though. While the East German Laender recorded high levels of debt, Saxony has a unique debt record as it has successfully managed to reduce initial debt levels in the course of the last decade. We are, however, reluctant to overstate evidence from the East German Laender including Berlin since the time series is relatively short.

With regard to the three city states (Berlin, Bremen and Hamburg) we conclude that they are significantly different regarding the standard ADF and PP unit root tests on public debt: Hamburg could be assumed to be sustainable while Bremen is I(1) and Berlin I(2). Therefore, we conclude that public finances in the German Laender are in need of consolidation. Further pressure on public finances of the Laender might arise from the repercussions of the German debt brake.

\section{References}

Afonso, A. (2005), 'Fiscal Sustainability: The Unpleasant European Case', Public Finance Analysis 61, $19-44$.

Bohn, H. (2008), 'The Sustainability of Fiscal Policy in the United States', pp. 15-49, in: R. Neck and J. Sturm (eds.), Sustainability of Public Debt, MIT: Cambridge London.

Bravo, A. and A. Silvestre (2002), 'Intertemporal Sustainability of Fiscal Policies: Some Tests for European Countries', European Journal of Political Economy 18, 517-528.

Burret, H. T., L. P. Feld and E. A. Köhler (2013), 'Sustainability of Public Debt in Germany - Historical Considerations and Time Series Evidence', Journal of Economics and Statistics 233, 291-335.

Burret, H. T., L. P. Feld and E. A. Köhler (2014), 'Panel Cointegration Tests on the Fiscal Sustainability of German Laender', Unpublished Working Paper, Walter Eucken Institute, Freiburg.

Campbell, J. Y. and P. Perron (1991), 'Pitfalls and Opportunities: What Macroeconomists Should Know about Unit Roots', NBER Macroeconomics Annual 6, 141-201.

Cheung, Y. W. and K. S. Lai (1995), 'Estimating Finite Sample Critical Values for Unit Root Tests Using Pure Random Walk Processes: A Note', Journal of Time Series Analysis 16, 493-498. 
Claeys, P., R. Ramos and J. Suriňach (2008), 'Fiscal Sustainability Across Government Tiers', International Economics and Economic Policy 5, 139-163.

Fincke, B. and A. Greiner (2011), 'Debt Sustainability in Germany: Empirical Evidence for Federal States', International Journal of Sustainable Economy 3, 235-254.

Glynn, J., N. Perera and R. Verma (2007), 'Unit Root Tests and Structural Breaks: A Survey with Applications', Revista de Métodos Cuantitativos para la Economia y la Empresa (Journal of Quantitiative Mehtods for Economcis and Business Administration) 3, 63-79.

Greiner, A. and G. Kauermann (2007), 'Sustainability of US Public Debt: Estimating Smoothing Spline Regressions', Economic Modelling 24, 350-364.

Greiner, A. and G. Kauermann (2008), 'Evidence for Germany and Italy Using Penalized Spline Smoothing', Economic Modelling 25, 1144-1154.

Greiner A., U. Köller and W. Semmler (2006), 'Testing the Sustainability of German Fiscal Policy: Evidence for the Period 1960-2003', Empirica 33, 127-140.

Grilli, V. (1988), 'Seigniorage in Europe', National Bureau of Economic Research (NBER) Working Paper 2778.

Herzog, B. (2010), 'Anwendung des Nachhaltigkeitsansatzes von Bohn zur Etablierung eines Frühindikators in den öffentlichen Finanzen', Kredit und Kapital 42, 183-206.

Hamilton, J. D. (1994), Time Series Analysis, Princeton University Press, Princeton.

Kitterer, W. (2007), 'Nachhaltige Finanz- und Investitionspolitik der Bundesländer', Perspektiven der Wirtschaftspolitik 8, 53-83.

Kirchgässner, G. and S. Prohl (2008), 'Sustainability of Swiss Fiscal Policy', Swiss Journal of Economics and Statistics 144, 57-83.

Koester, G. B. and C. Priesmeier (2013), 'Does Wagner's Law Ruin the Sustainability of German Public Finance?', Public Finance Analysis 69, 256-288.

Larin, B. and V. Süßmuth (2014), 'Fiscal Autonomy and Fiscal Sustainability: Subnational Taxation and Public Indebtedness in Contemporary Spain', CESifo Working Paper 4726.

Newey, W. K. and K. D. West (1994), 'Automatic Lag Selection in Covariance Matrix Estimation', Review of Economic Studies 61, 631-654.

Payne, J. (1997), 'International Evidence on the Sustainability of Budget Deficits', Applied Economics Letters 12, 775-779.

Polito, V. and M. Wickens (2011), 'Assessing the Fiscal Stance in the European Union and the United States 1970-2011', Economic Policy 26, 599-647. 


\section{Appendix}

\section{Table A.7 Data}

\begin{tabular}{|c|c|c|c|c|}
\hline Variable & Level & Period & Definition & Source \\
\hline $\begin{array}{l}\text { Expenditures and } \\
\text { revenues }\end{array}$ & $\begin{array}{l}\text { Laender } \\
\text { (without local level) }\end{array}$ & $\begin{array}{l}1950-1969 \\
1970-2011\end{array}$ & $\begin{array}{l}\text { Total revenues and total expenditures } \\
\text { Total revenues and total expenditures adjusted for } \\
\text { payments from the same level. Data in accordance } \\
\text { with cash statistics for } 2011 \text { and in accordance with } \\
\text { final annual accounting otherwise. }\end{array}$ & Federal Statistical Office \\
\hline Debt & $\begin{array}{l}\text { Laender } \\
\text { (without local level) }\end{array}$ & $1955-2011$ & $\begin{array}{l}\text { Since } 2006 \text { it includes most, and since } 2010 \text { all public } \\
\text { funds, institutions and companies. Data in } \\
\text { accordance with cash statistics for } 2011 \text { and in } \\
\text { accordance with final annual accounting otherwise. }\end{array}$ & Federal Statistical Office \\
\hline Population & Laender & $1950-2011$ & End of each year & Federal Statistical Office \\
\hline GDP per capita & Federal & $1950-2011$ & GDP in current prices & Federal Statistical Office \\
\hline
\end{tabular}

Note: Data for Saarland is not available before 1960. Data for East German Laender and whole of Berlin starts in 1992. Since 1960 is a short fiscal year (April - December), the values for 1960 regarding expenditure and revenue has been derived by interpolation and in the case of Saarland by extrapolation. Data is partly derived by a search request at the Federal Statistical Office.

Table A.8 Descriptive Statistics in General and by Laender Group

\begin{tabular}{|c|c|c|c|c|c|}
\hline Variable & Obs & Mean & Std. Dev. & Min & Max \\
\hline \multicolumn{6}{|l|}{ Expenditure } \\
\hline All Laender & 730 & 0.1458 & 0.0574 & 0.0680 & 0.3226 \\
\hline City states & 144 & 0.2528 & 0.0289 & 0.1987 & 0.3226 \\
\hline East non-city Laender & 100 & 0.1528 & 0.1497 & 0.1245 & 0.1973 \\
\hline West non-city Laender & 486 & 0.1127 & 0.0122 & 0.0680 & 0.1506 \\
\hline \multicolumn{6}{|l|}{ Revenue } \\
\hline All Laender & 730 & 0.1367 & 0.0524 & 0.0705 & 0.3144 \\
\hline City states & 144 & 0.2344 & 0.0295 & 0.1654 & 0.3144 \\
\hline East non-city Laender & 100 & 0.1413 & 0.0079 & 0.1265 & 0.1684 \\
\hline West non-city Laender & 486 & 0.1067 & 0.0104 & 0.0705 & 0.1511 \\
\hline \multicolumn{6}{|l|}{ Debt } \\
\hline All Laender & 685 & 0.1703 & 0.1437 & 0.0149 & 0.9009 \\
\hline City states & 134 & 0.3508 & 0.1978 & 0.0799 & 0.9009 \\
\hline East non-city Laender & 100 & 0.1682 & 0.0751 & 0.0226 & 0.2899 \\
\hline West non-city Laender & 451 & 0.1172 & 0.0779 & 0.0149 & 0.3921 \\
\hline
\end{tabular}

Note: City states include Bremen and Hamburg and since 1992 Berlin. East non-city Laender include Brandenburg, Mecklenburg-Western Pomerania, Saxony-Anhalt, Saxony and Thuringia. West non-city Laender include Bavaria, Baden-Wuerttemberg, Hessen, Lower Saxony, North-Rhine Westphalia, Rhineland-Palatinate, Schleswig-Holstein, and since 1960 Saarland.

\section{Table A.9 Time Series Test Results for Berlin}

Step 1: Unit root and stationary tests

\begin{tabular}{|c|c|c|c|c|c|}
\hline & & & Debt & Expenditure & Revenue \\
\hline \multirow[t]{3}{*}{ ADF } & \multirow{2}{*}{ Level } & Constant & $-2.876^{*}$ & $-3.996 * * *$ & -2.232 \\
\hline & & Constant and trend & -0.188 & -1.910 & -2.700 \\
\hline & $1^{\text {st }}$ differences & Constant & -2.225 & -1.965 & $-5.994 * * *$ \\
\hline \multirow[t]{3}{*}{ PP } & \multirow{2}{*}{ Level } & Constant & -2.876 & -0.726 & -2.232 \\
\hline & & Constant and trend & -0.303 & -2.456 & -2.640 \\
\hline & $1^{\text {st }}$ differences & Constant & -2.138 & $-4.832 * * *$ & $-6.165 * * *$ \\
\hline \multirow[t]{3}{*}{ KPSS } & \multirow{2}{*}{ Level } & Constant & $0.547 * *$ & $0.570 * *$ & $0.472 * *$ \\
\hline & & Constant and trend & $0.156 * *$ & 0.118 & $0.120 *$ \\
\hline & $1^{\text {st }}$ differences & Constant & $0.452^{*}$ & 0.094 & 0.170 \\
\hline \multirow[t]{2}{*}{ ZA } & \multirow{2}{*}{ Level } & Constant & $-2.408(2007)$ & $-3.048(2002)$ & $-4.588 *(2007)$ \\
\hline & & Constant and trend & $-3.094(2003)$ & n.s.m. & $-4.640(2007)$ \\
\hline \multicolumn{2}{|c|}{ Verdict } & & non-stationary & inconclusive & non-stationary \\
\hline
\end{tabular}

For notes see Table 1. 
Table A.10 Time Series Test Results for Brandenburg

Step 1: Unit root and stationary tests

\begin{tabular}{|c|c|c|c|c|c|}
\hline & & & Debt & Expenditure & Revenue \\
\hline \multirow[t]{3}{*}{ ADF } & \multirow{2}{*}{ Level } & Constant & $-3.731^{* *}$ & -0.441 & -2.014 \\
\hline & & Constant and trend & -2.038 & $-4.963 * * *$ & -2.732 \\
\hline & $1^{\text {st }}$ differences & Constant & -2.075 & $-4.883 * * *$ & $-3.712^{* *}$ \\
\hline \multirow[t]{3}{*}{$\mathrm{PP}$} & \multirow{2}{*}{ Level } & Constant & $-5.890 * * *$ & -0.283 & -2.072 \\
\hline & & Constant and trend & $-3.776 * *$ & $-4.963 * * *$ & -2.731 \\
\hline & $1^{\text {st }}$ differences & Constant & $-2.858^{*}$ & $-13.006 * * *$ & $-3.705^{* *}$ \\
\hline \multirow[t]{3}{*}{ KPSS } & \multirow{2}{*}{ Level } & Constant & $0.555^{* *}$ & $0.567 * *$ & 0.260 \\
\hline & & Constant and trend & $0.183^{* *}$ & $0.120^{*}$ & $0.121^{*}$ \\
\hline & $1^{\text {st }}$ differences & Constant & $0.503^{* *}$ & 0.237 & 0.187 \\
\hline \multirow[t]{2}{*}{ ZA } & \multirow{2}{*}{ Level } & Constant & $-3.427(2006)$ & $-6.923 * * *(2000)$ & $-4.355(2002)$ \\
\hline & & Constant and trend & $-4.483(2006)$ & $-5.820 * * *(2007)$ & n.s.m. \\
\hline Verdic & & & inconclusive & inconclusive & non-stationar \\
\hline
\end{tabular}

Step 2: Johansen test on cointegration between expenditure and revenue

\begin{tabular}{|c|c|c|c|}
\hline \multicolumn{4}{|c|}{ Constant and trend } \\
\hline Null hypothesis & Eigenvalue & Trace statistic & $5 \%$ critical value \\
\hline None & 0.628 & $27.635^{* *}$ & 25.872 \\
\hline \multirow[t]{2}{*}{ At most 1} & 0.371 & 8.804 & 12.518 \\
\hline & & \multicolumn{2}{|c|}{ Max. Eigenvalue statistic } \\
\hline 0 & 0.628 & $18.831^{*}$ & 19.387 \\
\hline 1 & 0.371 & 8.804 & 12.518 \\
\hline
\end{tabular}

Step 3: Test on sustainability vector $[1,-1]$ in cointegration relation between expenditures and revenues

\begin{tabular}{cccccc}
\hline \multicolumn{2}{c}{ Constant and trend } & & & & \\
Chi-Square & Prob. & Rev. & Exp. & Constant & Trend \\
\hline $9.147^{* * *}$ & 0.002 & 1.000 & -1.000 & 0.004 & -0.002 \\
& & & & & $(0.000)$ \\
& & & & & {$[-5.521]$}
\end{tabular}

For notes see Table 1.

Table A.11 Time Series Test Results for Bremen

Step 1: Unit root and stationary tests

\begin{tabular}{|c|c|c|c|c|c|}
\hline & & & Debt & Expenditure & Revenue \\
\hline \multirow[t]{3}{*}{ ADF } & \multirow{2}{*}{ Level } & Constant & 0.555 & -2.385 & $-3.348^{* *}$ \\
\hline & & Constant and trend & 2.670 & -2.670 & $-3.340 *$ \\
\hline & $1^{\text {st }}$ differences & Constant & $-3.979 * * *$ & $-7.379 * * *$ & $-3.129 * *$ \\
\hline \multirow[t]{3}{*}{$\mathrm{PP}$} & \multirow{2}{*}{ Level } & Constant & 0.928 & -2.560 & $-2.807^{*}$ \\
\hline & & Constant and trend & -2.026 & -2.835 & -2.734 \\
\hline & $1^{\text {st }}$ differences & Constant & $-3.932 * * *$ & $-7.379 * * *$ & $-8.789 * * *$ \\
\hline \multirow[t]{3}{*}{ KPSS } & \multirow{2}{*}{ Level } & Constant & $0.850 * * *$ & 0.215 & 0.104 \\
\hline & & Constant and trend & 0.085 & $0.128 *$ & 0.103 \\
\hline & $1^{\text {st }}$ differences & Constant & 0.283 & 0.138 & 0.120 \\
\hline \multirow[t]{2}{*}{ ZA } & \multirow{2}{*}{ Level } & Constant & $-3.625(1994)$ & $-4.456(1973)$ & $-3.304(2002)$ \\
\hline & & Constant and trend & n.s.m. & $-4.257(1991)$ & $-4.183(1991)$ \\
\hline Verdic & & & inconclusive & non-stationary & inconclusive \\
\hline
\end{tabular}

Step 2: Johansen test on cointegration between expenditure and revenue

\begin{tabular}{lccc}
\hline Constant & & & \\
Null hypothesis & Eigenvalue & Trace statistic & $5 \%$ critical value \\
\hline None & 0.138 & 14.950 & 15.459 \\
At most1 & 0.092 & $5.865^{* *}$ & 3.841 \\
& & Max. Eigenvalue statistic \\
\hline 0 & 0.138 & 9.087 & 14.265 \\
1 & 0.092 & $5.862^{* *}$ & 3.841 \\
For notes see Table 1. & &
\end{tabular}


Table A.12 Time Series Test Results for Hamburg

Step 1: Unit root and stationary tests

\begin{tabular}{|c|c|c|c|c|c|}
\hline & & & Debt & Expenditure & Revenue \\
\hline \multirow[t]{3}{*}{ ADF } & \multirow{2}{*}{ Level } & Constant & 0.020 & -2.097 & -2.425 \\
\hline & & Constant and trend & $-3.941 * *$ & -2.523 & $-4.192 * *$ \\
\hline & $1^{\text {st }}$ differences & Constant & $-5.889 * * *$ & $-8.148 * * *$ & $-9.181 * * *$ \\
\hline \multirow[t]{3}{*}{ PP } & \multirow{2}{*}{ Level } & Constant & -0.076 & -2.097 & -2.329 \\
\hline & & Constant and trend & $-3.637 * *$ & -2.613 & $-4.175 * * *$ \\
\hline & $1^{\text {st }}$ differences & Constant & $-5.797 * * *$ & $-8.505^{* * *}$ & $-12.282 * * *$ \\
\hline \multirow[t]{3}{*}{ KPSS } & \multirow{2}{*}{ Level } & Constant & $0.857^{* * *}$ & $0.504^{* *}$ & $0.814^{* * *}$ \\
\hline & & Constant and trend & $0.154^{* *}$ & $0.231^{* * *}$ & $0.179 * *$ \\
\hline & $1^{\text {st }}$ differences & Constant & 0.181 & 0.080 & 0.162 \\
\hline \multirow[t]{2}{*}{ ZA } & \multirow{2}{*}{ Level } & Constant & $-4.511(1993)$ & $-4.992 * *(1998)$ & $-5.669 * * *(1998)$ \\
\hline & & Constant and trend & n.s.m. & $-4.469(1998)$ & $-5.309 * *(1998)$ \\
\hline Verdic & & & inconclusive & non-stationary & inconclusive \\
\hline
\end{tabular}

Step 2: Johansen test on cointegration between expenditure and revenue

\begin{tabular}{lccc}
\hline Constant & & & \\
Null hypothesis & Eigenvalue & Trace statistic & $5 \%$ critical value \\
\hline None & 0.241 & $21.025^{* *}$ & 20.261 \\
At most1 & 0.066 & 4.176 & 9.165 \\
& & \multicolumn{2}{c}{ Max. Eigenvalue statistic } \\
\hline 0 & 0.241 & $16.849^{* *}$ & 15.892 \\
1 & 0.066 & 4.176 & 9.165
\end{tabular}

\begin{tabular}{lrcc}
\hline $\begin{array}{l}\text { Constant and trend } \\
\text { Null hypothesis }\end{array}$ & \multicolumn{3}{c}{ Eigenvalue } \\
\hline None & 0.438 & $41.667^{* * *}$ & 25.872 \\
At most 1 & 0.100 & 6.484 & 12.518 \\
& & \multicolumn{2}{c}{ Max. Eigenvalue statistic } \\
\hline 0 & 0.438 & $35.183^{* * *}$ & 19.387 \\
1 & 0.100 & 6.484 & 12.518
\end{tabular}

Step 3: Test on sustainability vector $[1,-1]$ in cointegration relation between expenditures and revenues

\begin{tabular}{ccccc}
\hline $\begin{array}{l}\text { Constant } \\
\text { Chi-Square }\end{array}$ & Prob. & Rev. & Exp. & Constant \\
\hline 0.069 & 0.790 & 1.000 & -1.000 & 0.011 \\
& & & & $(0.003)$ \\
& & & & {$[3.394]$}
\end{tabular}

\begin{tabular}{cccccc}
\hline \multicolumn{2}{c}{ Constant and trend } & & & & \\
Chi-Square & Prob. & Rev. & Exp. & Constant & Trend \\
\hline $12.434^{* * *}$ & 0.000 & 1.000 & -1.000 & 0.018 & 0.000 \\
& & & & & $(0.000)$ \\
& & & & {$[2.762]$}
\end{tabular}

For notes see Table 1.

Table A.13 Time Series Test Results for Lower Saxony

Step 1: Unit root and stationary tests

\begin{tabular}{|c|c|c|c|c|c|}
\hline & & & Debt & Expenditure & Revenue \\
\hline \multirow[t]{3}{*}{ ADF } & \multirow{2}{*}{ Level } & Constant & 0.110 & -2.208 & $-2.773 *$ \\
\hline & & Constant and trend & $-4.158 * * *$ & -1.708 & -2.686 \\
\hline & $1^{\text {st }}$ differences & Constant & $-4.483 * * *$ & $-5.583 * * *$ & $-8.541 * * *$ \\
\hline \multirow[t]{3}{*}{ PP } & \multirow{2}{*}{ Level } & Constant & -0.617 & -1.957 & $-2.655^{*}$ \\
\hline & & Constant and trend & $-3.701^{* *}$ & -1.737 & -2.531 \\
\hline & $1^{\text {st }}$ differences & Constant & $-4.183^{* * *}$ & $-7.665^{* * *}$ & $-9.501 * * *$ \\
\hline \multirow[t]{3}{*}{ KPSS } & \multirow{2}{*}{ Level } & Constant & $0.865^{* * *}$ & 0.338 & 0.241 \\
\hline & & Constant and trend & $0.149 * *$ & $0.226^{* * *}$ & $0.236^{* *}$ \\
\hline & $1^{\text {st }}$ differences & Constant & 0.326 & 0.175 & 0.302 \\
\hline \multirow[t]{2}{*}{ ZA } & \multirow{2}{*}{ Level } & Constant & $-4.437(1968)$ & $-3.364(1972)$ & $-5.669(1997)$ \\
\hline & & Constant and trend & n.s.m. & $-3.938(1974)$ & $-4.022(1977)$ \\
\hline \multicolumn{2}{|c|}{ Verdict } & & inconclusive & non-stationary & non-stationary \\
\hline
\end{tabular}

Step 2: Johansen test on cointegration between expenditure and revenue

\begin{tabular}{lccc}
\hline Constant & & & \\
Null hypothesis & Eigenvalue & Trace statistic & 5\% critical value \\
\hline None & 0.262 & $23.817^{* *}$ & 20.261 \\
At most1 & 0.083 & 5.293 & 9.165 \\
& & \multicolumn{2}{c}{ Max. Eigenvalue statistic } \\
\hline 0 & 0.261 & $18.524^{* *}$ & 15.892 \\
1 & 0.083 & 5.293 & 9.165
\end{tabular}

\begin{tabular}{lccc}
\hline $\begin{array}{l}\text { Constant and trend } \\
\text { Null hypothesis }\end{array}$ & \multicolumn{4}{c}{ Eigenvalue } & Trace statistic & 5\% critical value \\
\hline None & 0.327 & $29.881^{* *}$ & 25.872 \\
At most 1 & 0.087 & 5.578 & 12.518 \\
& & \multicolumn{2}{c}{ Max. Eigenvalue statistic } \\
\hline 0 & 0.327 & $24.303^{* *}$ & 19.387 \\
1 & 0.087 & 5.578 & 12.518
\end{tabular}


Step 3: Test on sustainability vector $[1,-1]$ in cointegration relation between expenditures and revenues

\begin{tabular}{lcccc}
\hline $\begin{array}{l}\text { Constant } \\
\text { Chi-Square }\end{array}$ & Prob. & Rev. & Exp. & Constant \\
\hline $10.250^{* * *}$ & 0.001 & 1.000 & -1.000 & 0.007 \\
& & & & $(0.002)$ \\
& & & & {$[3.291]$}
\end{tabular}

\begin{tabular}{lccccc}
\hline \multicolumn{2}{l}{ Constant and trend } & & & & \\
Chi-Square & Prob. & Rev. & Exp. & Constant & Trend \\
\hline $11.889 * * *$ & 0.000 & 1.000 & -1.000 & -0.0002 & 0.000 \\
& & & & & $(0.051)$ \\
& & & & & {$[2.534]$}
\end{tabular}

For notes see Table 1.

Table A.14 Time Series Test Results for Mecklenburg-Western Pomerania

Step 1: Unit root and stationary tests

\begin{tabular}{|c|c|c|c|c|c|}
\hline & & & Debt & Expenditure & Revenue \\
\hline \multirow[t]{3}{*}{ ADF } & \multirow{2}{*}{ Level } & Constant & -2.465 & -0.891 & -2.085 \\
\hline & & Constant and trend & 0.548 & $-3.955^{* *}$ & -2.621 \\
\hline & $1^{\text {st }}$ differences & Constant & -1.501 & $-3.554 * *$ & $-4.460 * * *$ \\
\hline \multirow[t]{3}{*}{ PP } & \multirow{2}{*}{ Level } & Constant & $-4.461 * * *$ & -0.961 & -2.085 \\
\hline & & Constant and trend & -1.002 & $-4.016^{* *}$ & -2.540 \\
\hline & $1^{\text {st }}$ differences & Constant & -1.131 & $-4.611 * * *$ & $-4.469 * * *$ \\
\hline \multirow[t]{3}{*}{ KPSS } & \multirow{2}{*}{ Level } & Constant & $0.513 * *$ & $0.447 * *$ & 0.270 \\
\hline & & Constant and trend & $0.168 * *$ & 0.100 & 0.009 \\
\hline & $1^{\text {st }}$ differences & Constant & $0.610 * *$ & 0.227 & 0.144 \\
\hline \multirow[t]{2}{*}{ ZA } & \multirow{2}{*}{ Level } & Constant & $-2.088(2006)$ & $-4.132(1999)$ & n.s.m. \\
\hline & & Constant and trend & n.s.m. & $-3.815(2007)$ & n.s.m. \\
\hline Verdic & & & non-stationary & inconclusive & inconclusiv \\
\hline
\end{tabular}

Step 2: Johansen test on cointegration between expenditure and revenue

\begin{tabular}{|c|c|c|c|}
\hline \multicolumn{4}{|c|}{ Constant and trend } \\
\hline Null hypothesis & Eigenvalue & Trace statistic & $5 \%$ critical value \\
\hline None & 0.553 & $22.245^{* * *}$ & 18.398 \\
\hline \multirow[t]{2}{*}{ At most 1} & 0.307 & $6.966 * * *$ & 3.841 \\
\hline & & \multicolumn{2}{|c|}{ Max. Eigenvalue statistic } \\
\hline 0 & 0.553 & 15.278 & 17.148 \\
\hline 1 & 0.307 & $3.340 * * *$ & 3.841 \\
\hline
\end{tabular}

Table A.15 Time Series Test Results for Saarland

Step 1: Unit root and stationary tests

\begin{tabular}{|c|c|c|c|c|c|}
\hline & & & Debt & Expenditure & Revenue \\
\hline \multirow[t]{3}{*}{ ADF } & \multirow{2}{*}{ Level } & Constant & -0.949 & -2.251 & -1.701 \\
\hline & & Constant and trend & -3.078 & -2.169 & -1.748 \\
\hline & $1^{\text {st }}$ differences & Constant & $-4.257 * * *$ & $-7.609 * * *$ & $-6.866 * * *$ \\
\hline \multirow[t]{3}{*}{ PP } & \multirow{2}{*}{ Level } & Constant & -0.483 & -2.301 & -1.944 \\
\hline & & Constant and trend & -1.849 & -2.226 & -1.997 \\
\hline & $1^{\text {st }}$ differences & Constant & $-4.277 * * *$ & $-7.619 * * *$ & $-8.789 * * *$ \\
\hline \multirow[t]{3}{*}{ KPSS } & \multirow{2}{*}{ Level } & Constant & $0.898 * * *$ & 0.206 & 0.139 \\
\hline & & Constant and trend & 0.096 & $0.185^{* *}$ & 0.112 \\
\hline & $1^{\text {st }}$ differences & Constant & 0.077 & 0.102 & 0.083 \\
\hline \multirow[t]{2}{*}{$\mathrm{ZA}$} & \multirow{2}{*}{ Level } & Constant & $-4.094(1994)$ & $-3.610(1997)$ & $-3.317(2001)$ \\
\hline & & Constant and trend & $-3.384(1981)$ & $-3.621(1973)$ & $-3.922(1991)$ \\
\hline Verdict & & & non-stationary & non-stationary & inconclusive \\
\hline
\end{tabular}

Step 2: Johansen test on cointegration between expenditure and revenue

\begin{tabular}{lccc}
\hline $\begin{array}{l}\text { Constant } \\
\text { Null hypothesis }\end{array}$ & Eigenvalue & Trace statistic & 5\% critical value \\
\hline None & 0.203 & $16.092^{* *}$ & 15.495 \\
At most1 & 0.094 & $4.492^{* *}$ & 3.841 \\
& & \multicolumn{2}{c}{ Max. Eigenvalue statistic } \\
\hline 0 & 0.242 & 11.600 & 14.264 \\
1 & 0.094 & 4.492 & 3.841 \\
For notes see Table 1. & &
\end{tabular}


Table A.16 Time Series Test Results for Saxony

Step 1: Unit root and stationary tests

\begin{tabular}{|c|c|c|c|c|c|}
\hline & & & Debt & Expenditure & Revenue \\
\hline \multirow[t]{3}{*}{ ADF } & \multirow{2}{*}{ Level } & Constant & -0.575 & -0.248 & -2.627 \\
\hline & & Constant and trend & 0.630 & $-4.576 * *$ & -3.260 \\
\hline & $1^{\text {st }}$ differences & Constant & -2.341 & $-4.330 * * *$ & $-3.735 * *$ \\
\hline \multirow[t]{3}{*}{$\mathrm{PP}$} & \multirow{2}{*}{ Level } & Constant & -1.845 & -0.509 & -2.619 \\
\hline & & Constant and trend & -1.219 & $-4.099 * *$ & $-4.930 * * *$ \\
\hline & $1^{\text {st }}$ differences & Constant & -2.344 & $-5.541 * * *$ & $-4.169 * * *$ \\
\hline \multirow[t]{3}{*}{ KPSS } & \multirow{2}{*}{ Level } & Constant & 0.165 & $0.532 * *$ & 0.160 \\
\hline & & Constant and trend & $0.165^{* *}$ & 0.077 & $0.122^{*}$ \\
\hline & $1^{\text {st }}$ differences & Constant & $0.507^{* *}$ & $0.500 * *$ & 0.229 \\
\hline \multirow[t]{2}{*}{ ZA } & \multirow{2}{*}{ Level } & Constant & $-0.335(2002)$ & $-5.787 * * *(2006)$ & $-3.737(2004)$ \\
\hline & & Constant and trend & n.s.m. & $-5.194 * *(2001)$ & n.s.m. \\
\hline Verdict & & & non-stationary & inconclusive & inconclusive \\
\hline
\end{tabular}

For notes see Table 1.

Table A.17 Time Series Test Results for Saxony-Anhalt

Step 1: Unit root and stationary tests

\begin{tabular}{|c|c|c|c|c|c|}
\hline & & & Debt & Expenditure & Revenue \\
\hline \multirow[t]{3}{*}{ ADF } & \multirow{2}{*}{ Level } & Constant & $-5.706 * * *$ & -1.251 & $-3.121 * *$ \\
\hline & & Constant and trend & 0.320 & -2.969 & -3.118 \\
\hline & $1^{\text {st }}$ differences & Constant & -1.907 & $-5.283^{* * *}$ & $-3.290 * *$ \\
\hline \multirow[t]{3}{*}{ PP } & \multirow{2}{*}{ Level } & Constant & $-5.367 * * *$ & -1.324 & $-3.096 * *$ \\
\hline & & Constant and trend & -0.678 & $-3.439 *$ & -3.220 \\
\hline & $1^{\text {st }}$ differences & Constant & -1.907 & $-4.668 * * *$ & $-4.735^{* * *}$ \\
\hline \multirow[t]{3}{*}{ KPSS } & \multirow{2}{*}{ Level } & Constant & $0.582 * *$ & $0.457^{*}$ & 0.120 \\
\hline & & Constant and trend & $0.168^{* *}$ & 0.101 & $0.123^{*}$ \\
\hline & $1^{\text {st }}$ differences & Constant & $0.636^{* *}$ & 0.183 & 0.172 \\
\hline \multirow[t]{2}{*}{$Z A$} & \multirow{2}{*}{ Level } & Constant & $-0.691(2002)$ & $-3.353(2007)$ & n.s.m \\
\hline & & Constant and trend & $-4.385(2005)$ & $-3.425(2007)$ & $-4.767(1998)$ \\
\hline Verdic & & & inconclusive & inconclusive & inconclusive \\
\hline
\end{tabular}

Step 2: Johansen test on cointegration between expenditure and revenue

Constant and trend

Null hypothesis Eigenvalue Trace statistic 5\% critical value

\begin{tabular}{lccc}
\hline None & 0.445 & $20.213^{* * *}$ & 18.398 \\
At most 1 & 0.378 & $9.016^{* * *}$ & 3.841 \\
& & Max. Eigenvalue statistic \\
0 & 0.445 & 11.196 & 17.148 \\
1 & 0.378 & $9.016^{* * *}$ & 3.841
\end{tabular}

Table A.18 Time Series Test Results for Schleswig-Holstein

Step 1: Unit root and stationary tests

\begin{tabular}{|c|c|c|c|c|c|}
\hline & & & Debt & Expenditure & Revenue \\
\hline \multirow[t]{3}{*}{ ADF } & \multirow[b]{2}{*}{ Level } & Constant & 1.486 & -2.589 & $-3.016^{* *}$ \\
\hline & & Constant and trend & $-3.459 *$ & -2.592 & $-4.484 * * *$ \\
\hline & $1^{\text {st }}$ differences & Constant & $-4.595 * * *$ & $-6.621 * * *$ & $-7.488 * * *$ \\
\hline \multirow[t]{3}{*}{$\mathrm{PP}$} & \multirow{2}{*}{ Level } & Constant & 1.363 & $-2.598 *$ & $-3.140 * *$ \\
\hline & & Constant and trend & $-3.875 * *$ & -2.385 & $-4.485^{* * *}$ \\
\hline & $1^{\text {st }}$ differences & Constant & $-6.517 * * *$ & $-8.864 * * *$ & $-13.006 * * *$ \\
\hline \multirow[t]{3}{*}{ KPSS } & \multirow{2}{*}{ Level } & Constant & $0.888 * * *$ & 0.232 & $0.455^{*}$ \\
\hline & & Constant and trend & $0.137^{*}$ & $0.232 * * *$ & $0.150 * *$ \\
\hline & $1^{\text {st }}$ differences & Constant & $0.392 *$ & $0.361^{*}$ & 0.269 \\
\hline \multirow[t]{2}{*}{ ZA } & \multirow{2}{*}{ Level } & Constant & $-3.837(1977)$ & $-3.893(1998)$ & $-5.800 * * *(1998)$ \\
\hline & & Constant and trend & n.s.m. & $-3.313(1974)$ & $-5.503 * *(1991)$ \\
\hline Verdict & & & non-stationary & non-stationary & inconclusive \\
\hline
\end{tabular}


Step 2: Johansen test on cointegration between expenditure and revenue

\begin{tabular}{|c|c|c|c|}
\hline \multicolumn{4}{|c|}{ Constant and trend } \\
\hline Null hypothesis & Eigenvalue & Trace statistic & $5 \%$ critical value \\
\hline None & 0.354 & $34.677^{* *}$ & 25.872 \\
\hline \multirow[t]{2}{*}{ At most 1} & 0.123 & 7.984 & 12.518 \\
\hline & & \multicolumn{2}{|c|}{ Max. Eigenvalue statistic } \\
\hline 0 & 0.354 & $26.693 * *$ & 19.387 \\
\hline 1 & 0.123 & 7.984 & 12.518 \\
\hline
\end{tabular}

Step 3: Test on sustainability vector $[1,-1]$ in cointegration relation between expenditures and revenues

\begin{tabular}{lccccc}
\hline \multicolumn{2}{l}{ Constant and trend } & & & & \\
Chi-Square & Prob. & Rev. & Exp. & Constant & Trend \\
\hline $11.403^{* * *}$ & 0.000 & 1.000 & -1.000 & -0.0005 & 0.000 \\
& & & & & $(0.057)$ \\
& & & & & {$[3.265]$}
\end{tabular}

For notes see Table 1.

Table A.19 Time Series Test Results for Thuringia

Step 1: Unit root and stationary tests

\begin{tabular}{|c|c|c|c|c|c|}
\hline & & & Debt & Expenditure & Revenue \\
\hline \multirow[t]{3}{*}{ ADF } & \multirow{2}{*}{ Level } & Constant & $-5.517 * * *$ & -0.377 & -2.035 \\
\hline & & Constant and trend & -0.490 & $-4.442 * *$ & $-3.517^{*}$ \\
\hline & $1^{\text {st }}$ differences & Constant & -1.941 & $-5.264 * * *$ & $-4.502 * * *$ \\
\hline \multirow[t]{3}{*}{ PP } & \multirow{2}{*}{ Level } & Constant & $-5.023 * * *$ & -0.377 & -1.549 \\
\hline & & Constant and trend & -1.196 & $-4.368 * *$ & -2.681 \\
\hline & $1^{\text {st }}$ differences & Constant & -1.171 & $-5.616 * * *$ & $-4.481 * * *$ \\
\hline \multirow[t]{3}{*}{ KPSS } & \multirow{2}{*}{ Level } & Constant & $0.554 * *$ & $0.510 * *$ & 0.307 \\
\hline & & Constant and trend & $0.168 * *$ & $0.126^{*}$ & 0.112 \\
\hline & $1^{\text {st }}$ differences & Constant & $0.625^{* *}$ & 0.290 & 0.227 \\
\hline \multirow[t]{2}{*}{$Z A$} & \multirow{2}{*}{ Level } & Constant & $-2.820(2007)$ & $-5.089 *(2002)$ & $-3.967(2002)$ \\
\hline & & Constant and trend & $-3.191(2004)$ & $-4.626(2006)$ & n.s.m. \\
\hline Verdict & & & inconclusive & inconclusive & inconclusive \\
\hline
\end{tabular}

Step 2: Johansen test on cointegration between expenditure and revenue

\begin{tabular}{|c|c|c|c|}
\hline \multicolumn{4}{|c|}{ Constant and trend } \\
\hline Null hypothesis & Eigenvalue & Trace statistic & $5 \%$ critical value \\
\hline None & 0.593 & $22.621^{* *}$ & 18.397 \\
\hline \multirow[t]{2}{*}{ At most 1} & 0.252 & $5.524 * * *$ & 3.841 \\
\hline & & \multicolumn{2}{|c|}{ Max. Eigenvalue statistic } \\
\hline 0 & 0.593 & $17.097^{*}$ & 17.148 \\
\hline 1 & 0.252 & $5.520 * *$ & 3.841 \\
\hline
\end{tabular}

